\title{
Infrared Brazing Cu and Ti Using a 95Ag-5Al Braze Alloy
}

\begin{abstract}
R.K. SHIUE, S.K. WU, and C.H. CHAN
Dynamic wetting angle measurements, microstructural evolution, reaction kinetics, and shear strength of infrared brazing $\mathrm{Cu}$ and $\mathrm{Ti}$ using a $95 \mathrm{Ag}-5 \mathrm{Al}$ braze alloy are evaluated. The specimen infrared brazed at $900{ }^{\circ} \mathrm{C}$ consists mainly of $\mathrm{Cu}_{2} \mathrm{Ti}$ and $\mathrm{Cu}_{4} \mathrm{Ti}$. Both $\mathrm{CuTi}$ and $\mathrm{Cu}_{4} \mathrm{Ti}_{3}$ are observed at the interface between the braze and Ti substrate. Microstructures of Ti/95Ag-5Al/Cu joints infrared brazed at $830{ }^{\circ} \mathrm{C}$ and $850{ }^{\circ} \mathrm{C}$ are very different from that of the joint infrared brazed at $900{ }^{\circ} \mathrm{C}$, because the dissolution of both substrates significantly decreased as the brazing temperature decreased. Specimens infrared brazed at $830{ }^{\circ} \mathrm{C}$ and $850{ }^{\circ} \mathrm{C}$ are primarily comprised of $\mathrm{Ag}-\mathrm{Cu}$ eutectic and the $\mathrm{Cu}$-rich phase. Two interfacial reaction layers, including $\mathrm{Ti}_{2} \mathrm{Cu}$ and $\mathrm{AlCu}_{2} \mathrm{Ti}$, are found in the experiment. The shear strengths of infrared brazed specimens at $830{ }^{\circ} \mathrm{C}$ and $850{ }^{\circ} \mathrm{C}$ are between 160 and $198.5 \mathrm{MPa}$, and are fractured along the interfacial reaction layers, $\mathrm{AlCu}_{2} \mathrm{Ti}$ and $\mathrm{Ti}_{2} \mathrm{Cu}$, between the braze alloy and $\mathrm{Ti}$ substrate. The use of the infrared brazing provides an effective way to inhibit the growth of intermetallics at the interface between the braze alloy and substrate.
\end{abstract}

\section{INTRODUCTION}

THE joining of pure titanium and copper currently is applied for the production of titanium targets used in physical vapor deposition (PVD) infrastructures. In this process, it is desirable that the high-purity titanium target is bonded with the water-cooled oxygen-free copper substrate without significant loss of its thermal conductivity. Brazing is often one of the best choices in manufacturing of the Ti target due to the high thermal conductivity of the brazed joint as compared with adhesive bonding. ${ }^{[1,2]}$ It has been reported that the titanium alloy can be successfully brazed with several silver-based braze alloys, ${ }^{[2-6]}$ and $95 \mathrm{Ag}-5 \mathrm{Al}$ in weight percent is a type of silver-based braze alloy. The melting point of pure Ag is significantly decreased with 5 wt pct $\mathrm{Al}$ additions, resulting in solidus and liquidus temperatures of $95 \mathrm{Ag}-5 \mathrm{Al}$ braze being $780{ }^{\circ} \mathrm{C}$ and $810^{\circ} \mathrm{C}$, respectively. ${ }^{[2]}$

Infrared heating is a novel technique characterized by an extraordinary fast heating rate up to $3000{ }^{\circ} \mathrm{C} / \mathrm{min} .{ }^{[7]}$ Thus, the interfacial reaction among the molten braze and substrates during infrared brazing may be greatly decreased due to the rapid thermal history. Accordingly, there are many successfully infrared-brazed joints demonstrated in previous studies. ${ }^{[7-10]}$ This research investigates infrared brazing $\mathrm{Cu}$ and $\mathrm{Ti}$ using the 95Ag-5Al braze alloy. Dynamic wetting angle measurement, microstructural evolution, reaction kinetics across the brazed joint, and shear strength are comprehensively evaluated in the experiment.

\section{MATERIAL AND EXPERIMENTAL PROCEDURES}

The base metals used in the experiment were commercially pure titanium plate and oxygen-free copper plate. $95 \mathrm{Ag}$ -

R.K. SHIUE, Associate Professor and S.K. WU, Professor, are with the Department of Materials Science and Engineering, National Taiwan University, Taipei 106, Taiwan. C.H. CHAN, former Graduate Student, is with the Department of Mechanical Engineering, National Taiwan University, Taipei 106, Taiwan. Contact e-mail: skw@ccms.ntu.edu.tw

Manuscript submitted December 12, 2003.
$5 \mathrm{Al}$ alloy was chosen as the brazing filler metal, and braze alloy foil with thickness of $100 \mu \mathrm{m}$ was used throughout the experiment.

Figure 1(a) illustrates the schematic diagram of the wetting angle measurement device. The instrument was composed of three major parts, an infrared vacuum furnace, a specimen holder, and the image analysis system. The ULVAC*

*ULVAC is a trademark of ULVAC Japan, Ltd., Japan.

SINKO-RIKO RHL-P816C infrared furnace was used as the main body of the vacuum furnace. The measurement was performed in a vacuum of $5 \times 10^{-5}$ mbar throughout the experiment. Infrared rays were generated from the infrared lamps, transmitting through a transparent quartz tube and focused on the specimen holder. One end of the quartz tube was attached to the specimen holder, and the other end could transmit the signal into the image analysis system. An enlarged diagram of the specimen holder is shown in Figure 1(b). The filler metal was located on the substrate $(\mathrm{Cu}$ or $\mathrm{Ti})$, and a thermocouple was simultaneously in contact with the substrate. A graphite holder below the substrate was used in order to enhance the absorptivity of the infrared rays.

The braze alloy (95Ag-5Al, wt pct) with near spherical shape used in the wetting angle test was prepared from the foil by vacuum arc remelting with the operation voltage of $60 \mathrm{~V}$ and 50 to $60 \mathrm{~A}$. The weight of each sphere was kept to approximately $0.12 \mathrm{~g}$. There was an alumina plate next to the filler metal and substrate. The alumina plate was used as the background of the filler metal image during the wetting angle measurements. The image of the molten braze on the substrate was captured simultaneously by a charge coupled device (CCD) at a constant frequency of 20 frames per second. The active pixels of the CCD camera were $768(\mathrm{H}) \times 494(\mathrm{~V})$. The CCD images were then saved in a computer for further analyses.

The heating rate was set at $900{ }^{\circ} \mathrm{C} / \mathrm{min}$ throughout the experiment. All samples were preheated to $500{ }^{\circ} \mathrm{C}$ for 90 seconds before heating to the brazing temperature. Table I summarizes all process variables used in infrared brazing copper and titanium. After infrared brazing, the cross section of the brazed specimens was examined using either a LEO*

*LEO is a trademark of Carl Zeiss, Corp., Germany. 


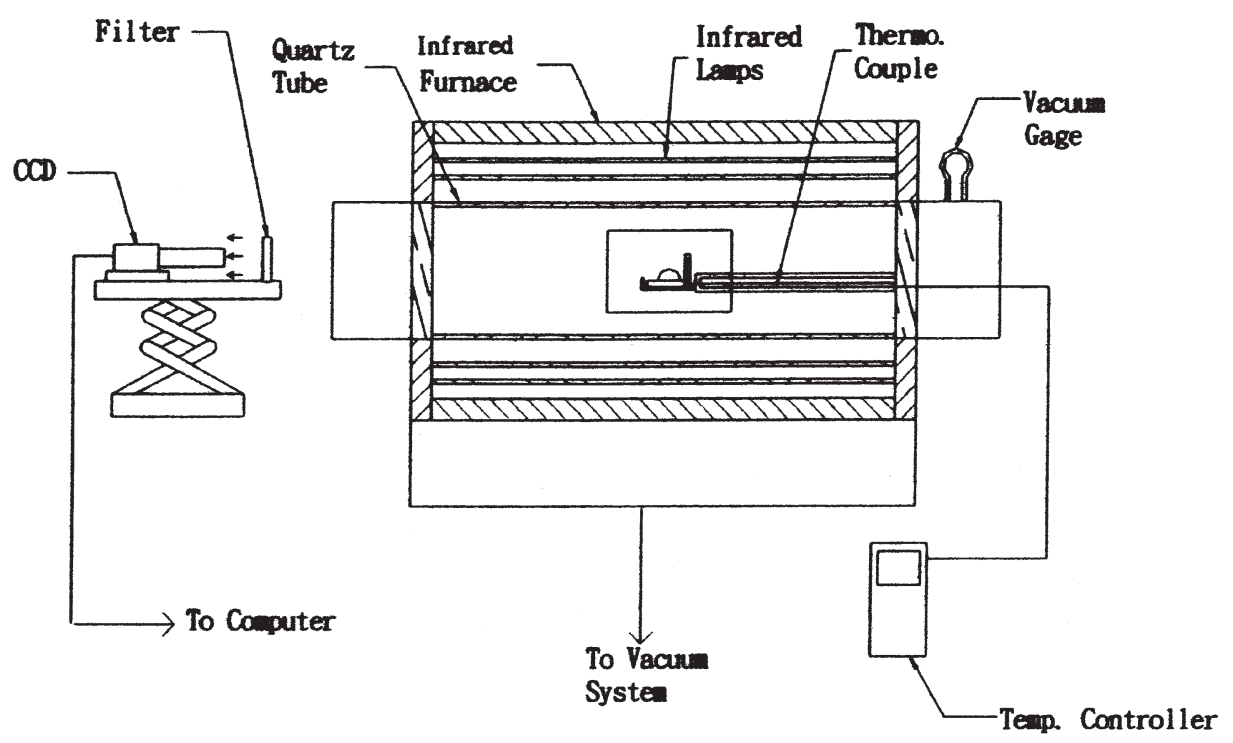

(a)

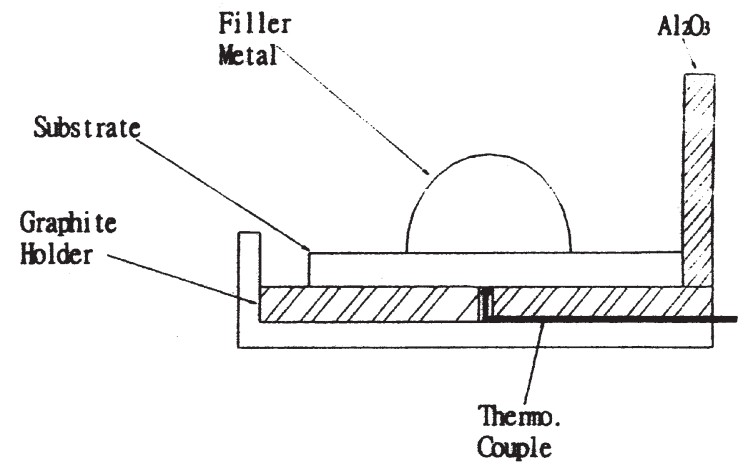

(b)

Fig. 1-Schematic diagram of (a) wetting angle measurement facility and (b) specimen holder in (a).

Table I. Process Variables Used in the Infrared Brazing

\begin{tabular}{lcccc}
\hline $\begin{array}{l}\text { Filler Metal } \\
\text { (Wt Pct) }\end{array}$ & Time (s) & $830{ }^{\circ} \mathrm{C}$ & $850{ }^{\circ} \mathrm{C}$ & $900{ }^{\circ} \mathrm{C}$ \\
\hline $95 \mathrm{Ag}-5 \mathrm{Al}$ & 60 & $\mathrm{M} / \mathrm{S}$ & $\mathrm{M} / \mathrm{S}$ & $\mathrm{M}$ \\
& 300 & $\mathrm{M} / \mathrm{S}$ & $\mathrm{M} / \mathrm{S}$ & $\mathrm{M}$ \\
\hline
\end{tabular}

M: metallographic observation specimen, and S: shear test specimen.

1530 field emission scanning electron microscope (FESEM) or a PHILIPS* XL-30 scanning electron microscope (SEM)

*PHILIPS is a trademark of Philips Electronic Instruments Corp., Mahwah, NJ.

with an accelerating voltage of $15 \mathrm{kV}$. Quantitative chemical analyses were performed using a JEOL** JXL-8600SX

**JEOL is a trademark of Japan Electron Optics Ltd., Tokyo.

electron probe microanalyzer (EPMA) with an operation voltage of $20 \mathrm{kV}$ and spot size of $1 \mu \mathrm{m}$.

Shear tests were performed in order to evaluate the bonding strength of selected infrared-brazed specimens. ${ }^{[6,7,9]}$ A Shimadzu*

*Shimadzu is a trademark of Shimadzu Corp., Japan.
AG-10 universal testing machine compressed the infraredbrazed specimen with a constant speed of $1 \mathrm{~mm} / \mathrm{min}$. The fractured surface after the shear test was examined by SEM followed by a structural analysis. The structural analysis was performed using a PHILIPS PW1710 X-ray diffractometer with $\mathrm{Cu} K_{\alpha}$ selected as the X-ray source. The X-ray scan rate was set at $4 \mathrm{deg} / \mathrm{min}$, and its range was between 20 and $90 \mathrm{deg}$.

\section{RESULTS AND DISCUSSION}

A. Dynamic Wetting Angle Measurements of 95Ag-5Al on Both Ti and Cu Substrates

The image capture rate of the CCD was kept at 20 frames per second, so there were 6000 frames during 0 to 300 seconds. Additionally, there were two wetting angles between the molten braze and the substrate observed from each CCD captured image. The contact angle was obtained from averaging both right-side and left-side wetting angles of every CCD captured image. Figure 2 shows the time-dependent contact angle of $95 \mathrm{Ag}-5 \mathrm{Al}$ braze on Ti substrate at $830{ }^{\circ} \mathrm{C}$, $850{ }^{\circ} \mathrm{C}$, and $900{ }^{\circ} \mathrm{C}$ for various time periods, respectively. It should be noted that the time period ( $X$-axis in Figure 2 ) is counted after the $95 \mathrm{Ag}-5 \mathrm{Al}$ braze alloy is melted during the test. According to Figure 2, the wetting angle of the 


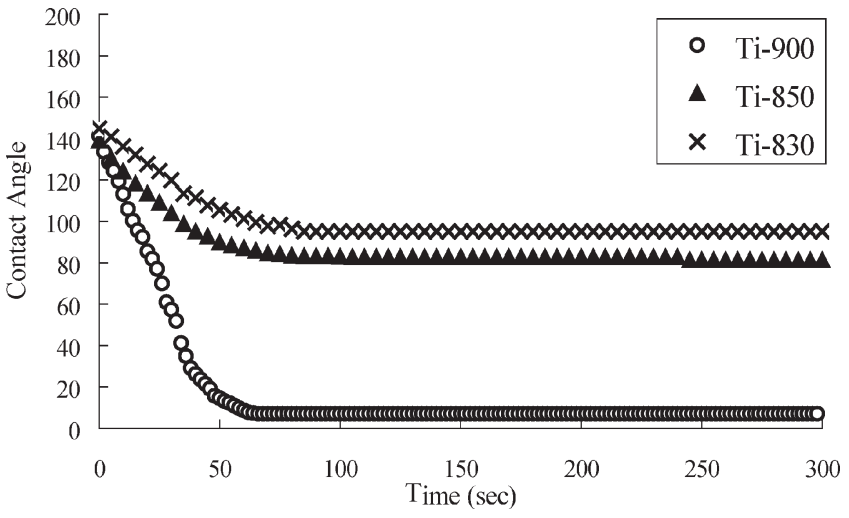

Fig. 2-Time-dependent contact angle of $95 \mathrm{Ag}-5 \mathrm{Al}$ braze on Ti substrate.

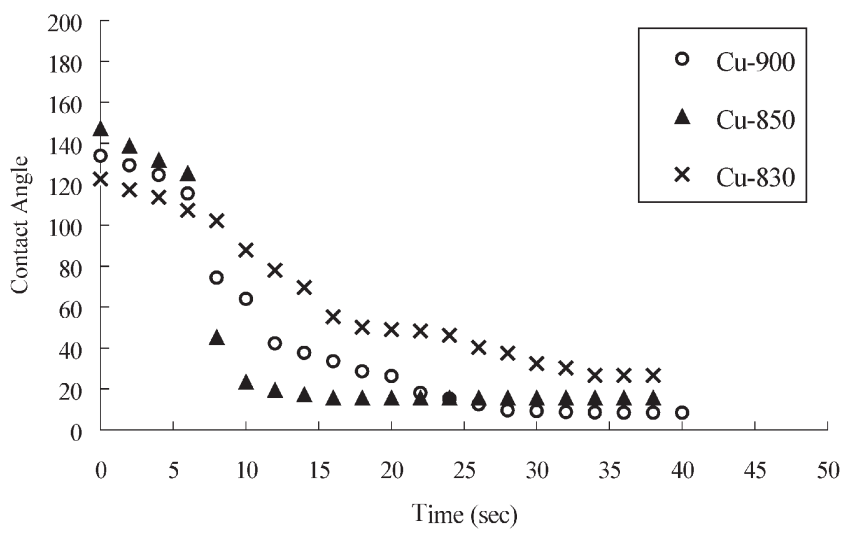

Fig. 3-Time-dependent contact angle of $95 \mathrm{Ag}-5 \mathrm{Al}$ braze on $\mathrm{Cu}$ substrate.

molten braze on the Ti substrate tested at $830{ }^{\circ} \mathrm{C}$ is as high as $100 \mathrm{deg}$. The wetting angle decreases with an increase in the testing temperature. It is also noted that the wetting angle decreases significantly in the first 50 seconds for the specimen tested at $900{ }^{\circ} \mathrm{C}$, and the molten $95 \mathrm{Ag}-5 \mathrm{Al}$ braze can completely wet the Ti substrate after 65 seconds.

Figure 3 displays the time-dependent contact angles of $95 \mathrm{Ag}-$ $5 \mathrm{Al}$ braze on $\mathrm{Cu}$ substrate at $830{ }^{\circ} \mathrm{C}, 850{ }^{\circ} \mathrm{C}$, and $900{ }^{\circ} \mathrm{C}$, respectively. In contrast to Figure 2, the molten braze demonstrates excellent wettability on the $\mathrm{Cu}$ substrate for all testing temperatures. For instance, the $\mathrm{Cu}$ substrate is readily wetted by the molten $95 \mathrm{Ag}-5 \mathrm{Al}$ braze at $900{ }^{\circ} \mathrm{C}$ after 10 seconds. It is also noted that the fluctuation of wetting angles for the $\mathrm{Cu}$ substrate is much more prominent than that of Ti substrate, as can be seen from a comparison of Figures 2 and 3. This is probably caused by high reflectivity of the $\mathrm{Cu}$ substrate during infrared heating, which may result in high temperature fluctuations during the wetting angle measurement. Consequently, the fluctuation in wetting angle measurement of the $\mathrm{Cu}$ substrate is much more prominent than that of Ti substrate.

\section{B. Microstructural Evolution of the Infrared-Brazed Specimen}

Figure 4 shows the SEM backscattered electron images (BEIs) of Ti/95Ag-5Al/Cu specimens that were infrared brazed at various brazing conditions. The microstructure of infrared-brazed Ti/95Ag-5Al/Cu joints at $900{ }^{\circ} \mathrm{C}$ is very different from that of $\mathrm{Ti} / 95 \mathrm{Ag}-5 \mathrm{Al} / \mathrm{Cu}$ joints infrared brazed at $830{ }^{\circ} \mathrm{C}$ and $850{ }^{\circ} \mathrm{C}$ since cracks are observed from the infrared brazed joint at $900{ }^{\circ} \mathrm{C}$, as illustrated in Figures 4 (e) and (f). In contrast, sound joints are formed for the specimens infrared brazed at $830{ }^{\circ} \mathrm{C}$ and $850{ }^{\circ} \mathrm{C}$. The EPMA chemical investigations have been performed in order to identify various phases in the brazed joint.

Figure 5 shows the SEM BEI and EPMA results of the Ti/95Ag-5Al/Cu joint infrared brazed at $900{ }^{\circ} \mathrm{C}$ for 60 seconds. The microstructure of the $\mathrm{Ti} / 95 \mathrm{Ag}-5 \mathrm{Al} / \mathrm{Cu}$ joint is very similar to that of previously investigated $\mathrm{Ti} / \mathrm{Ag} / \mathrm{Cu}$ joints. ${ }^{[11]}$ The infrared-brazed joint mainly consists of $\mathrm{Cu}_{2} \mathrm{Ti}$ (marked as D) and $\mathrm{Cu}_{4} \mathrm{Ti}$ (marked as E). There are at least three interfacial phases, including Ti-rich (marked as A), CuTi (marked as B), and $\mathrm{Cu}_{4} \mathrm{Ti}_{3}$ (marked as $\mathrm{C}$ ), as illustrated in Figure 5. It is unusual that the Ag-rich phase is not observed across the infrared-brazed joint based on the experimental observations. The Ag-Cu-Ti ternary alloy phase diagram is cited here in order to explain the disappearance of the Ag content in the brazed joint.

Figure 6 shows the liquidus projection of the $\mathrm{Ag}-\mathrm{Cu}-\mathrm{Ti}$ ternary alloy phase diagram in atomic percent and weight percent, respectively. ${ }^{[12,13]}$ According to Figure 6(a), there is a huge miscibility gap among the liquids for temperatures above $850{ }^{\circ} \mathrm{C}$, with point $\mathrm{c}_{1}$ at approximately $850{ }^{\circ} \mathrm{C} .^{[11,12]}$ The molten braze tends to separate into two liquids, an Ag-rich liquid and a liquid rich in $\mathrm{Cu}$ and $\mathrm{Ti}$ for temperatures exceeding $850^{\circ} \mathrm{C}$. For instance, there are two immiscible liquids, $\mathrm{L}_{1}$ and $\mathrm{L}_{2}$, at $900{ }^{\circ} \mathrm{C}$, and the reaction scheme is as formulated as ${ }^{[12]}$

$$
\mathrm{L}_{1}^{\prime \prime}+\mathrm{CuTi} \leftrightarrow \mathrm{L}_{2}^{\prime \prime}+\mathrm{Cu}_{4} \mathrm{Ti}_{3} \quad\left(900^{\circ} \mathrm{C}\right)
$$

The $\mathrm{L}_{1}$ " liquid is rich in $\mathrm{Cu}$ and $\mathrm{Ti}$, while $\mathrm{L}_{2}$ " liquid is $\mathrm{Ag}$ rich. According to the experimental observations, the Ag-rich liquid $\left(\mathrm{L}_{2}^{\prime \prime}\right)$ overflows out of the joint, so only the liquid rich in $\mathrm{Ti}$ and $\mathrm{Cu}\left(\mathrm{L}_{1}{ }^{\prime \prime}\right)$ is left in the joint. It is deduced that the overflow of the Ag-rich liquid $\left(\mathrm{L}_{2}{ }^{\prime \prime}\right)$ results from the existence of the miscibility gap in the Ag-Cu-Ti ternary phase diagram. In addition, both $\mathrm{CuTi}$ and $\mathrm{Cu}_{4} \mathrm{Ti}_{3}$ are observed at the interface between the braze and Ti substrate, as illustrated in Figure 5. The binary $\mathrm{Cu}$-Ti phase diagram is quoted here, because the infrared-brazed joint is mainly comprised of $\mathrm{Cu}$ and $\mathrm{Ti}$. According to the $\mathrm{Cu}$-Ti phase diagram, a series of invariant reactions upon cooling of the liquid are found: ${ }^{[1,14]}$

$$
\begin{gathered}
\mathrm{Cu}_{4} \mathrm{Ti}_{3}+\mathrm{L} \leftrightarrow \mathrm{Cu}_{2} \mathrm{Ti} \quad \text { (peritectic, } 890^{\circ} \mathrm{C} \pm 10^{\circ} \mathrm{C} \text { ) [2] } \\
\mathrm{L} \leftrightarrow \mathrm{Cu}_{2} \mathrm{Ti}+\beta \mathrm{Cu}_{4} \mathrm{Ti} \quad \text { (eutectic, } 875^{\circ} \mathrm{C} \pm 10^{\circ} \mathrm{C} \text { ) [3] }
\end{gathered}
$$

If the solidification of molten braze obeys the previous equations, then the residual molten braze is completely solidified into $\mathrm{Cu}_{2} \mathrm{Ti}$ and $\mathrm{Cu}_{4} \mathrm{Ti}$. Accordingly, the experimental results, as demonstrated in Figure 5, are in accordance with the $\mathrm{Cu}$-Ti binary alloy phase diagram.

Figure 7 displays the SEM BEIs and EPMA chemical analysis results of the $\mathrm{Ti} / 95 \mathrm{Ag}-5 \mathrm{Al} / \mathrm{Cu}$ specimen infrared brazed at $850{ }^{\circ} \mathrm{C}$ for 300 seconds. It is noted that there is no interfacial reaction layer between the braze and $\mathrm{Cu}$ substrate. However, at least two reaction layers are observed at the interface between the braze and Ti substrate, and the presence of reaction layers probably impairs the dissolution of substrate. Based on the EPMA chemical analyses, the infrared-brazed joint is primarily comprised of $\mathrm{Cu}$-rich and 

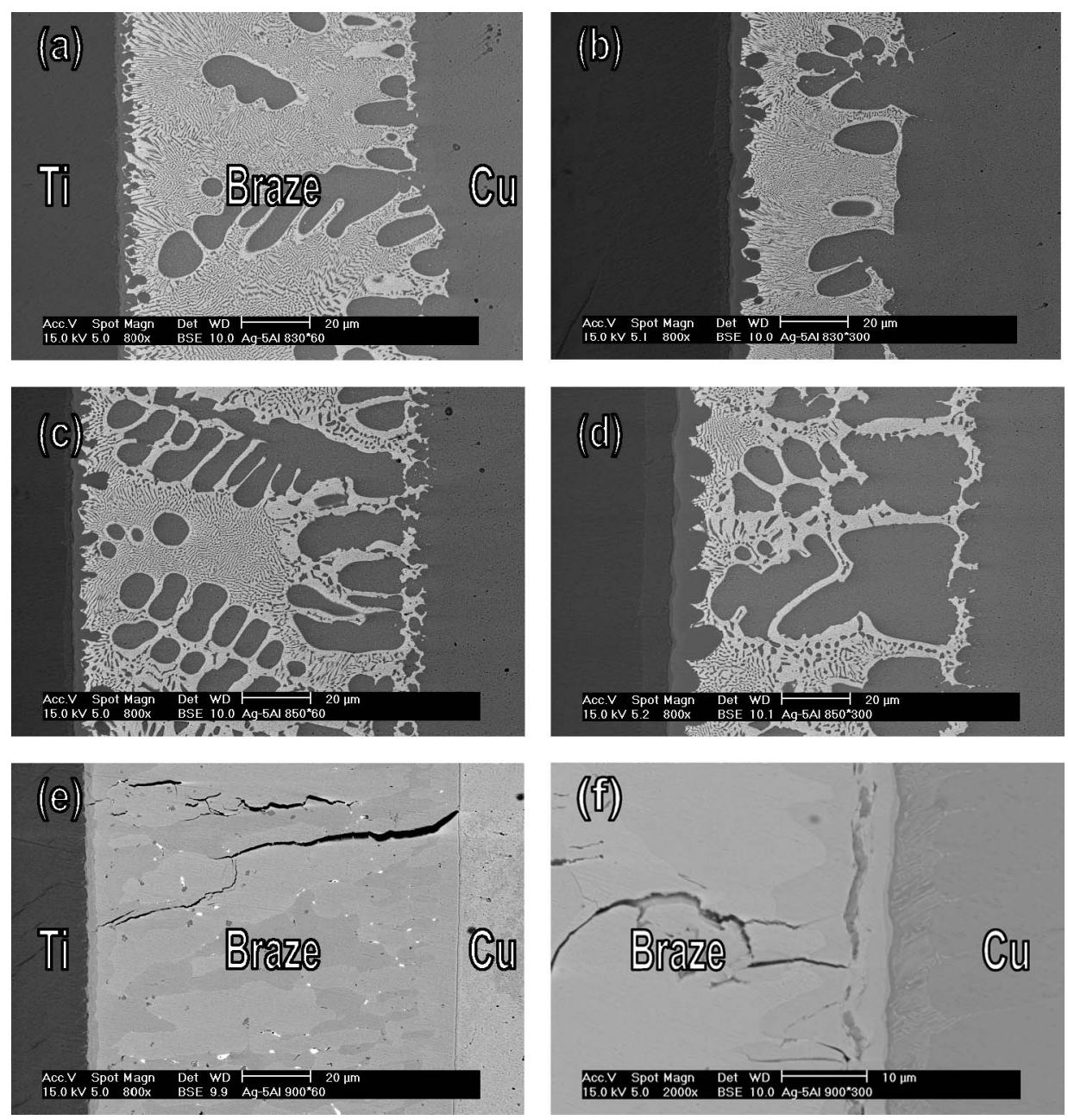

Fig. 4-SEM BEIs of Ti/Ag-5Al/Cu joints infrared brazed at (a) $830{ }^{\circ} \mathrm{C}, 60 \mathrm{~s} ;\left(\right.$ b) $830{ }^{\circ} \mathrm{C}, 300 \mathrm{~s} ;(c) 850{ }^{\circ} \mathrm{C}, 60 \mathrm{~s} ;(d) 850{ }^{\circ} \mathrm{C}, 300 \mathrm{~s} ;(e) 900{ }^{\circ} \mathrm{C}, 60 \mathrm{~s}$; and $(f) 900{ }^{\circ} \mathrm{C}, 300 \mathrm{~s}$.
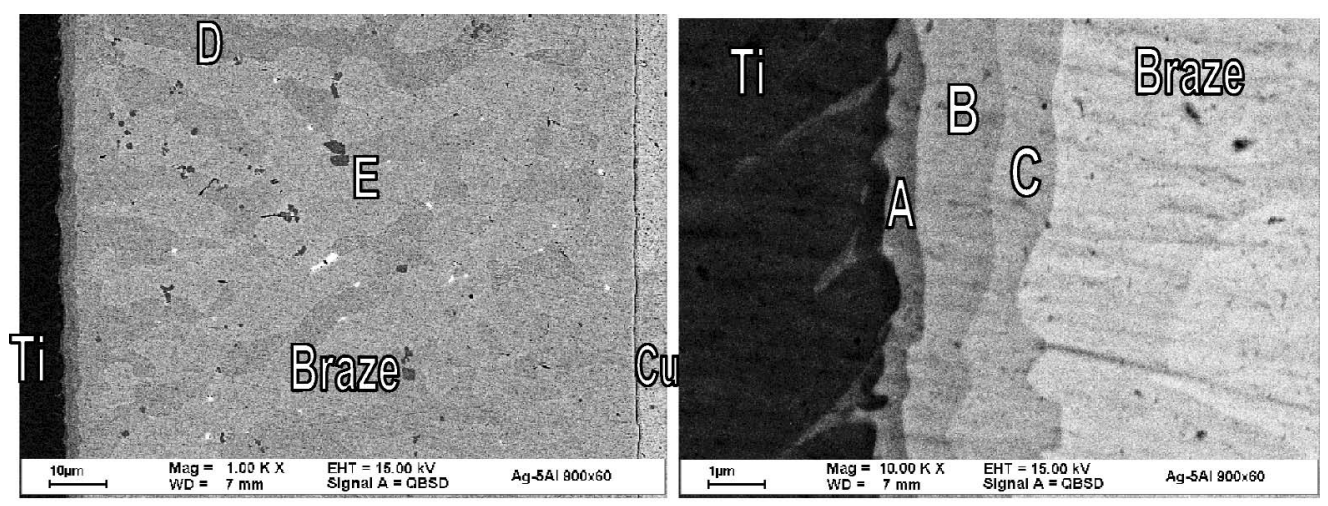

\begin{tabular}{cccccc}
\hline at $\%$ & $\mathrm{~A}$ & $\mathrm{~B}$ & $\mathrm{C}$ & $\mathrm{D}$ & $\mathrm{E}$ \\
\hline $\mathrm{Al}$ & 0.0 & 0.4 & 0.0 & 0.0 & 0.0 \\
$\mathrm{Ag}$ & 0.3 & 0.3 & 0.5 & 1.0 & 0.3 \\
$\mathrm{Cu}$ & 29.4 & 49.9 & 54.7 & 65.4 & 78.4 \\
$\mathrm{Ti}$ & 70.3 & 49.4 & 44.8 & 33.6 & 21.3 \\
Phase & (Ti-rich) & $\mathrm{CuTi}$ & $\mathrm{Cu}_{4} \mathrm{Ti}_{3}$ & $\mathrm{Cu}_{2} \mathrm{Ti}$ & $\mathrm{Cu}_{4} \mathrm{Ti}$ \\
\hline
\end{tabular}

Fig. 5-SEM BEI and EPMA results of Ti/95Ag-5Al/Cu joint infrared brazed at $900{ }^{\circ} \mathrm{C}$ for $60 \mathrm{~s}$. 


\section{$\mathrm{Ag}-\mathrm{Cu}-\mathrm{Ti} \quad \mathrm{Cu} \quad$ liquidus projection}

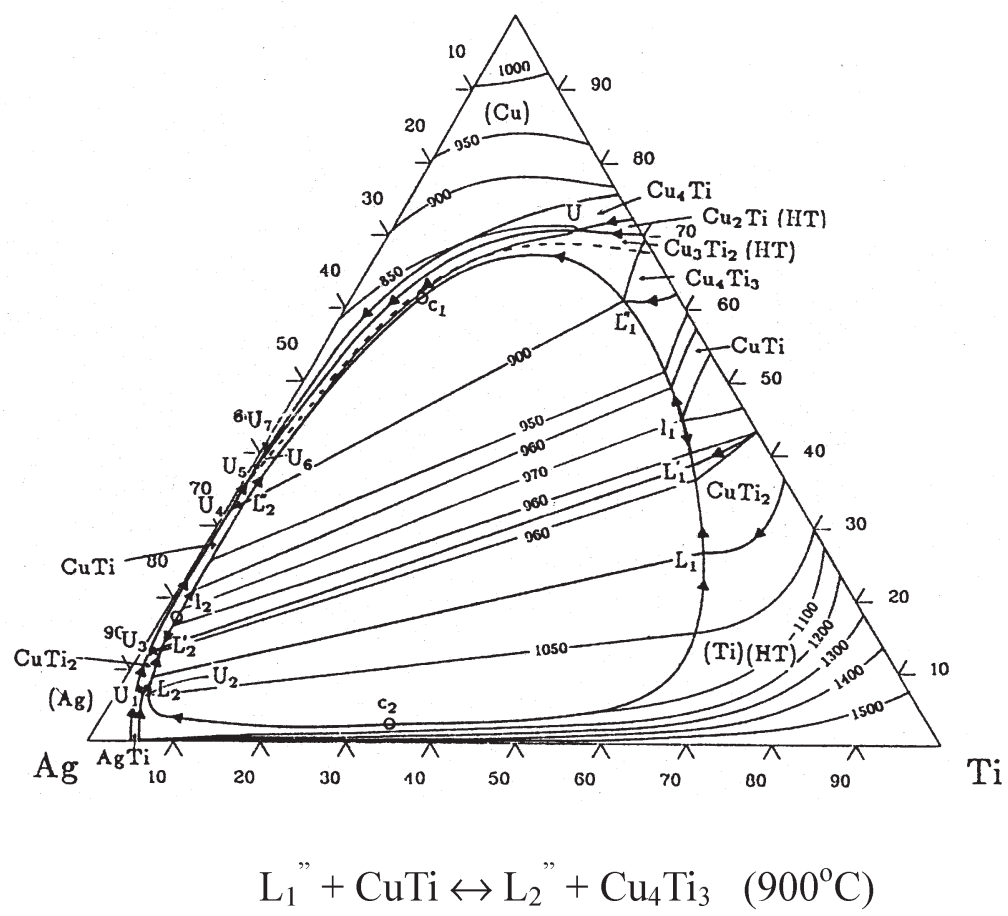

(a)

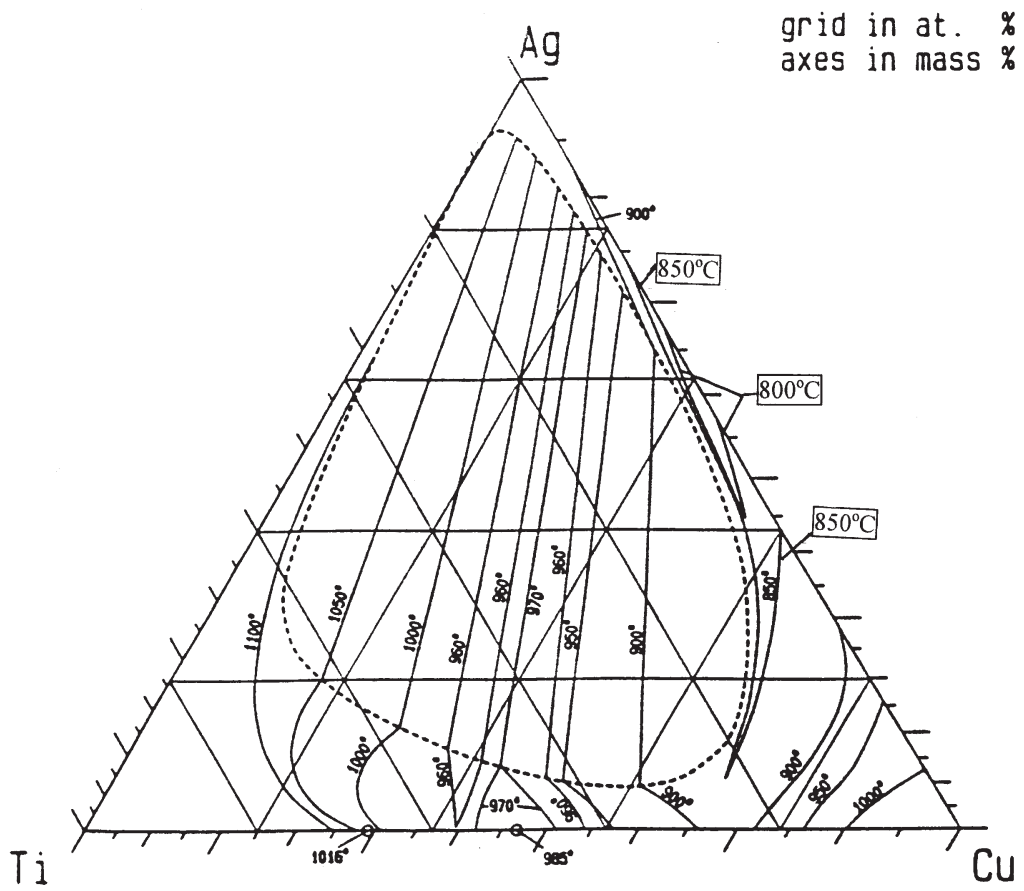

(b)

Fig. 6-Liquidus projection of Ag-Cu-Ti ternary alloy phase diagram in (a) atomic percent and $(b)$ weight percent. ${ }^{[12,13]}$

$\mathrm{Ag}-\mathrm{Cu}$ eutectic as marked by $\mathrm{D}$ and $\mathrm{E}$ in Figure 7, respectively. Figure 8 shows the isothermal section of the Ag-Al$\mathrm{Cu}$ ternary alloy phase diagram in atomic percent at $575^{\circ} \mathrm{C} \cdot .^{[12]}$ Both $\mathrm{Ag}$ and $\mathrm{Cu}$ can dissolve very large amounts of $\mathrm{Al}$, up to 20 at. pct. In contrast, the maximum solubility of $\mathrm{Ti}$ in a $\mathrm{Cu}$ matrix is less than 1 at. pct at $500{ }^{\circ} \mathrm{C}$, and the maximum solubility of $\mathrm{Ag}$ in $\mathrm{Cu}$ matrix is approximately 2 at. pct at $600{ }^{\circ} \mathrm{C} .{ }^{[14]}$ Therefore, it is expected that both the primary $\mathrm{Cu}$-rich phase and $\mathrm{Ag}$-Cu eutectic are alloyed with much more $\mathrm{Al}$ than $\mathrm{Ti}$, which is consistent with the experimental results (Figure 7). In general, the infrared-brazed joint at $850{ }^{\circ} \mathrm{C}$ is comprised of a primary $\mathrm{Cu}$-rich phase and $\mathrm{Ag}-\mathrm{Cu}$ eutectic. 


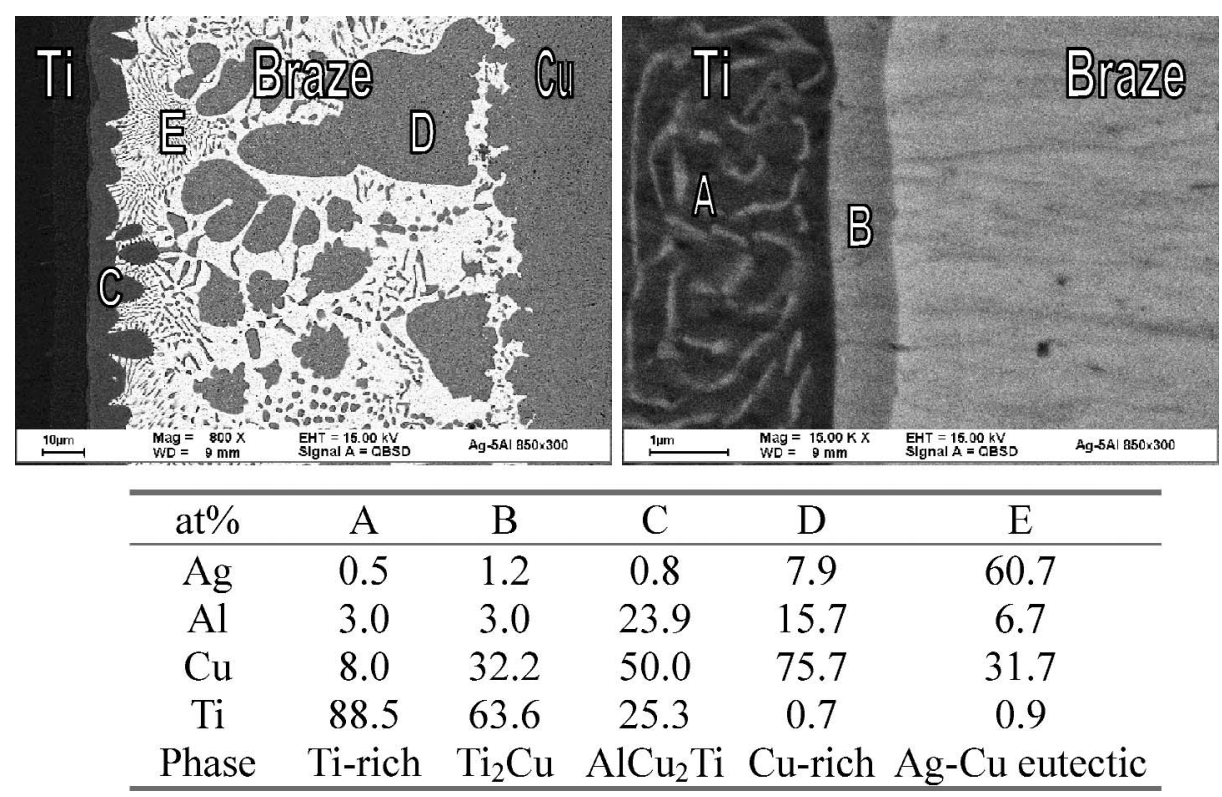

Fig. 7-SEM BEI and EPMA chemical analysis results of the Ti/95Ag-5Al/Cu joint infrared brazed at $850{ }^{\circ} \mathrm{C}$ for $300 \mathrm{~s}$.

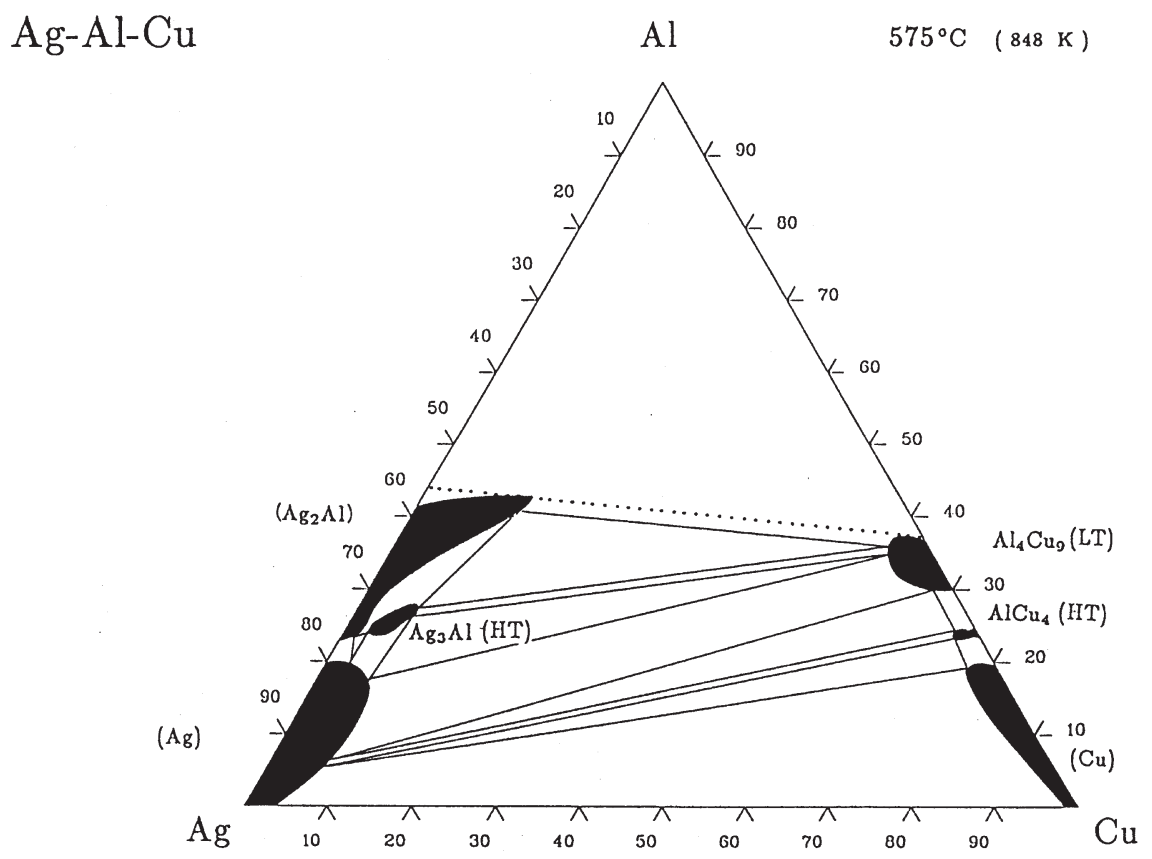

Fig. 8-Isothermal section of Ag-Al-Cu ternary alloy phase diagram at $575{ }^{\circ} \mathrm{C} .{ }^{[12]}$

The change of braze alloy composition from $95 \mathrm{Ag}-5 \mathrm{Al}$ into $\mathrm{Ag}-\mathrm{Cu}$ is caused by significant dissolution of $\mathrm{Cu}$ substrate into the molten braze during infrared brazing at $850{ }^{\circ} \mathrm{C}$. In contrast, the dissolution of Ti substrate is much less prominent as compared with that of $\mathrm{Cu}$ substrate. This can be explained by limited solubility of $\mathrm{Ti}$ in $\mathrm{Ag}-\mathrm{Cu}$ molten braze below $850{ }^{\circ} \mathrm{C}$ (Figure 6(b)) or the formation of interfacial reaction layer(s) between the molten braze and Ti substrate (Figure 7).

Based on the EPMA chemical analysis, there are at least two interfacial reaction layers in the joint, as shown in Figure 7. The stoichiometric ratio of $\mathrm{Ti}$ and $\mathrm{Cu}$ in phase $\mathrm{B}$ is close to $\mathrm{Ti}_{2} \mathrm{Cu}$. Similarly, the stoichiometric ratio between $\mathrm{Al}$,
$\mathrm{Cu}$, and $\mathrm{Ti}$ of phase $\mathrm{C}$ is close to $\mathrm{AlCu}_{2} \mathrm{Ti}$. The formation of $\mathrm{AlCu}_{2} \mathrm{Ti}$ phase indicates that Ti preferentially reacts with $\mathrm{Al}$ and $\mathrm{Cu}$, instead of with $\mathrm{Ag}$ in the molten braze alloy. It has been previously reported that the $\mathrm{AlCu}_{2} \mathrm{Ti}$ phase is observed at the TiAl boundary in brazing TiAl and INCONEL* 909

*INCONEL is a trademark of INCO Alloys International, Hutington Woods, WV.

using the $72 \mathrm{Ag}-28 \mathrm{Cu}$ (wt pct) braze alloy. ${ }^{[15]}$ This was formed by the reaction of $\mathrm{Ti}, \mathrm{Al}$, and $\mathrm{Cu}$ during brazing, and it had a very high hardness of $\mathrm{Hv} 700,{ }^{[15]}$ which is in agreement with the experimental observations of this work. 

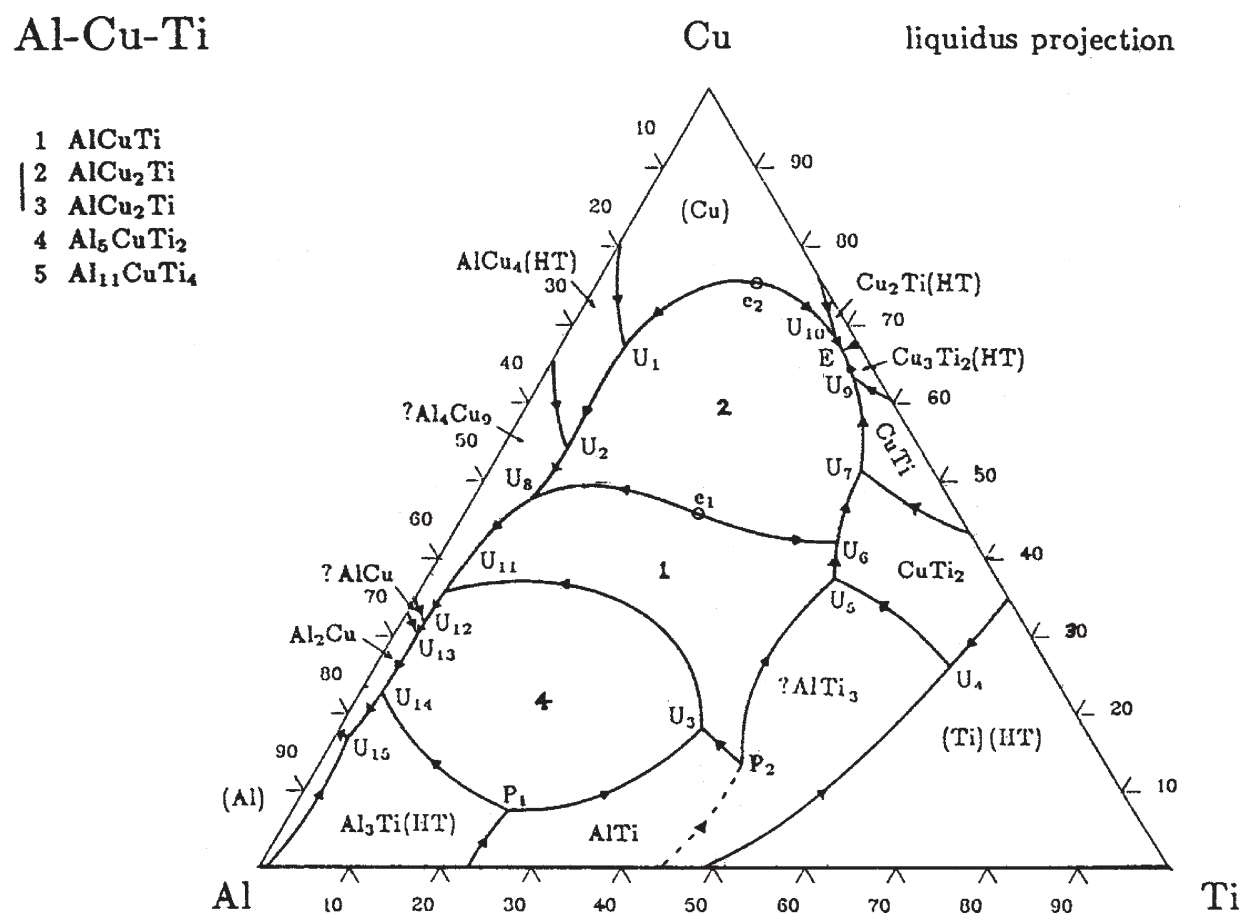

Fig. 9-Liquidus projection of Al-Cu-Ti ternary alloy phase diagram in atomic percent. ${ }^{[7,12]}$
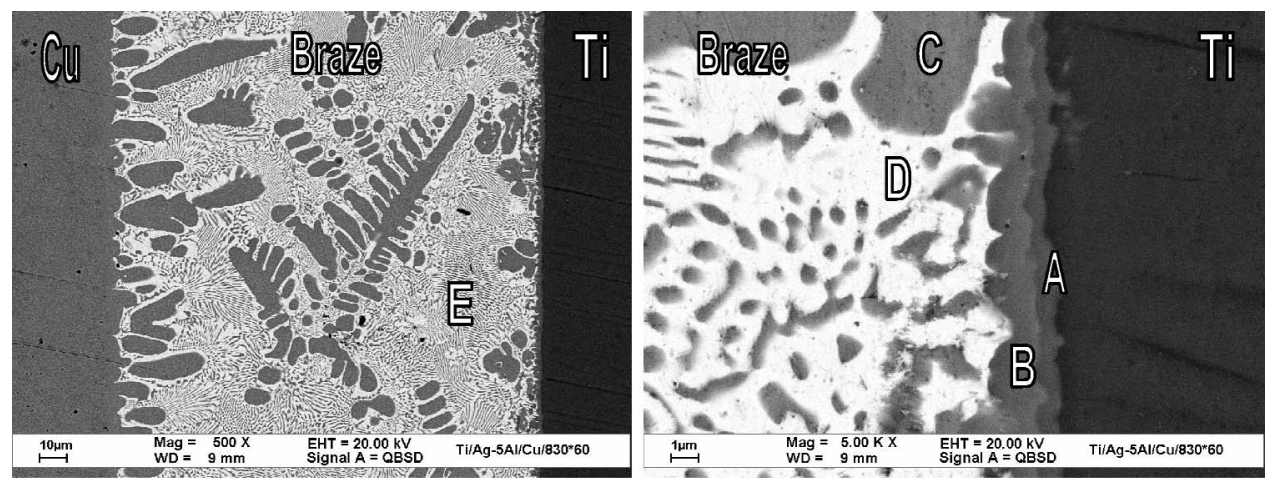

\begin{tabular}{cccccc}
\hline $\mathrm{At} \%$ & $\mathrm{~A}$ & $\mathrm{~B}$ & $\mathrm{C}$ & $\mathrm{D}$ & $\mathrm{E}$ \\
\hline $\mathrm{Ag}$ & 1.2 & 0.8 & 2.7 & 80.9 & 54.4 \\
$\mathrm{Al}$ & 3.0 & 23.9 & 18.1 & 4.7 & 6.8 \\
$\mathrm{Cu}$ & 32.2 & 50.0 & 78.6 & 13.1 & 38.1 \\
$\mathrm{Ti}$ & 63.6 & 25.3 & 0.6 & 1.2 & 0.7 \\
Phase & $\left(\mathrm{Ti}_{2} \mathrm{Cu}\right)$ & $\mathrm{AlCu}_{2} \mathrm{Ti}$ & Cu-rich & Ag-rich & Ag-Cu eutectic \\
\hline
\end{tabular}

Fig. 10-SEM BEI and EPMA chemical analysis results of the Ti/95Ag-5 Al/Cu joint infrared brazed at $830{ }^{\circ} \mathrm{C}$ for $60 \mathrm{~s}$.

Figure 9 illustrates the liquidus projection of Al-Cu-Ti ternary alloy phase diagram in atomic percent. ${ }^{[7,12]}$ Because the equilibrium temperatures of all invariant reactions close to $\mathrm{AlCu}_{2} \mathrm{Ti}$ phase far exceed $850{ }^{\circ} \mathrm{C}$, the interfacial $\mathrm{AlCu}_{2}$ Ti reaction layer is solidified from the molten braze during infrared brazing at $850{ }^{\circ} \mathrm{C}$ (or $830{ }^{\circ} \mathrm{C}$ ). This is evidenced by the irregular morphology of the $\mathrm{AlCu}_{2} \mathrm{Ti}$ phase (marked as $\mathrm{C}$ ), as illustrated in
Figure 7. It also can be noted that the morphology of $\mathrm{AlCu}_{2} \mathrm{Ti}$ phase is very different from that of the interfacial $\mathrm{Ti}_{2} \mathrm{Cu}$ phase, as marked by $\mathrm{B}$ in Figure 7. According to Figure 9, both $\mathrm{AlCu}_{2} \mathrm{Ti}$ and $\mathrm{Ti}_{2} \mathrm{Cu}$ phases share boundary curve, as do the $\mathrm{Ti}_{2} \mathrm{Cu}$ phase and $\mathrm{Ti}$ substrate. There are no other phases other than $\mathrm{Ti}_{2} \mathrm{Cu}$ between $\mathrm{AlCu}_{2} \mathrm{Ti}$ and $\mathrm{Ti}$. The average cooling rate is approximately $20{ }^{\circ} \mathrm{C} / \mathrm{min}$ after infrared brazing. Thus, it is 
reasonable to deduce that the $\mathrm{Ti}_{2} \mathrm{Cu}$ phase with the smooth interface is probably the result of the solid-state interdiffusion between $\mathrm{AlCu}_{2} \mathrm{Ti}$ phase and the Ti substrate.

Figure 10 shows both the SEM BEI and EPMA chemical analysis results of the Ti/95Ag-5Al/Cu joint infrared brazed at $830{ }^{\circ} \mathrm{C}$ for 60 seconds. Similar to the specimen infrared brazed at $850{ }^{\circ} \mathrm{C}$ for 300 seconds, the brazed joint is mainly comprised of the $\mathrm{Ag}-\mathrm{Cu}$ eutectic and $\mathrm{Cu}$-rich phase, as marked by points $\mathrm{C}$ through $\mathrm{E}$ in Figure 10. There are at least two interfacial reaction layers, $\mathrm{Ti}_{2} \mathrm{Cu}$ (marked as $\mathrm{A}$ ) and $\mathrm{AlCu}_{2} \mathrm{Ti}$ (marked as B), as illustrated in the figure. The thickness of the interfacial $\mathrm{AlCu}_{2} \mathrm{Ti}$ phase is greatly decreased as the brazing condition changes from $850{ }^{\circ} \mathrm{C}, 300$ seconds to $830^{\circ} \mathrm{C}, 60 \mathrm{sec}-$ onds According to Figure 6(b), dissolution of the Ti substrate into the molten braze is significantly decreased by decreasing the brazing temperature from $850^{\circ} \mathrm{C}$ to $830^{\circ} \mathrm{C}$. Accordingly, the growth of interfacial $\mathrm{AlCu}_{2} \mathrm{Ti}$ phase is inhibited due to insufficient Ti transport from Ti substrate into the molten braze during infrared brazing. Although the use of the infrared brazing cannot completely eliminate formation of the interfacial reaction layer(s), infrared brazing provides an effective way to inhibit the growth of intermetallics at the interface between the braze alloy and substrate. Additionally, the dissolution of both substrates during infrared brazing can be greatly decreased because of its rapid thermal history.

\section{Wetting Behavior of 95Ag-5Al Braze on $\mathrm{Cu}$ and $\mathrm{Ti}$ Substrates}

As discussed earlier, the molten braze demonstrates excellent wettability on the $\mathrm{Cu}$ substrate for all testing temperatures. However, the wetting angle of the molten braze on the Ti substrate tested at $830{ }^{\circ} \mathrm{C}$ is as high as $100 \mathrm{deg}$, but its wetting angle is decreased as the testing temperature increases. Accordingly, the molten $95 \mathrm{Ag}-5 \mathrm{Al}$ braze can effectively wet the Ti substrate at $900{ }^{\circ} \mathrm{C}$, and the dissolution of the substrate into the molten braze plays an important role in the wetting behavior of the $95 \mathrm{Ag}-5 \mathrm{Al}$ braze alloy.

Figure 6(b) displays the liquidus surface of the Ag-Cu-Ti ternary alloy phase diagram in weight percent. ${ }^{[13]}$ The reaction scheme below $850{ }^{\circ} \mathrm{C}$ is very different from that of $900{ }^{\circ} \mathrm{C}$, because there is no miscibility gap below $850{ }^{\circ} \mathrm{C}$. Both $\mathrm{Cu}$ and Ti substrates are dissolved into the molten $95 \mathrm{Ag}-5 \mathrm{Al}$ braze. However, the dissolution of $\mathrm{Cu}$ substrate into the molten braze is much more prominent than that of Ti substrate. The dissolution of $\mathrm{Cu}$ substrate is very prominent for all testing temperatures, so the molten braze demonstrates excellent wettability on the $\mathrm{Cu}$ substrate. In contrast, the dissolution of Ti substrate into the molten braze is significantly decreased as the testing temperature decreases from $900{ }^{\circ} \mathrm{C}$ to $800{ }^{\circ} \mathrm{C} \cdot{ }^{[13]}$ The solubility of $\mathrm{Ti}$ in $\mathrm{Ag}-\mathrm{Cu}-\mathrm{Ti}$ liquid at $800{ }^{\circ} \mathrm{C}$ is as low as $5 \mathrm{wt}$ pet, as shown in Figure 6(b). Apparently, the decrease of Ti substrate dissolved into the molten braze may result in poor wettability of the braze alloy tested below $850{ }^{\circ} \mathrm{C}$ (Figure 2).

In addition to dissolution of the substrate into the molten braze during the wetting angle test, the types of interfacial reaction layers also play an important role in wetting behavior of the $95 \mathrm{Ag}-5 \mathrm{Al}$ braze on the Ti substrate. The formation of the $\mathrm{AlCu}_{2} \mathrm{Ti}$ interfacial reaction layer at $850{ }^{\circ} \mathrm{C}$ or $830{ }^{\circ} \mathrm{C}$ greatly deteriorates the wettability of the molten braze on the Ti substrate. In contrast, the presence of the interfacial $\mathrm{CuTi}$ and $\mathrm{Cu}_{4} \mathrm{Ti}_{3}$ reaction layers is beneficial for the wettability
Table II. The Shear Strength of Infrared-Brazed Cu/95Ag-5Al/Ti Specimens

\begin{tabular}{lccc}
\hline $\begin{array}{l}\text { Brazing } \\
\text { Temperature }\end{array}$ & Brazing Time & Shear Strength & $\begin{array}{c}\text { Average } \\
\text { Shear Strength }\end{array}$ \\
\hline $830{ }^{\circ} \mathrm{C}$ & $60 \mathrm{~s}$ & $164 \mathrm{MPa}$ & $163.5 \mathrm{MPa}$ \\
& $60 \mathrm{~s}$ & $163 \mathrm{MPa}$ & \\
$830{ }^{\circ} \mathrm{C}$ & $300 \mathrm{~s}$ & $186 \mathrm{MPa}$ & $190.5 \mathrm{MPa}$ \\
& $300 \mathrm{~s}$ & $195 \mathrm{MPa}$ & \\
$850{ }^{\circ} \mathrm{C}$ & $60 \mathrm{~s}$ & $197 \mathrm{MPa}$ & $198.5 \mathrm{MPa}$ \\
& $60 \mathrm{~s}$ & $200 \mathrm{MPa}$ & \\
$850{ }^{\circ} \mathrm{C}$ & $300 \mathrm{~s}$ & $141 \mathrm{MPa}$ & $160.0 \mathrm{MPa}$ \\
& $300 \mathrm{~s}$ & $180 \mathrm{MPa}$ & \\
\hline
\end{tabular}

of the molten $95 \mathrm{Ag}-5 \mathrm{Al}$ braze on the Ti substrate, as illustrated in Figure 2.

\section{Mechanical Evaluation of the Infrared-Brazed Specimen}

Because there are cracks observed for the infrared-brazed specimen at $900{ }^{\circ} \mathrm{C}$, as shown in Figures 4(e) and (f), it is advised that the infrared brazing temperature should be below $900{ }^{\circ} \mathrm{C}$ in order to avoid the formation of brittle phase(s) in the joint. Shear tests were performed for specimens infrared brazed at $830{ }^{\circ} \mathrm{C}$ and $850{ }^{\circ} \mathrm{C}$, respectively. Table II shows the shear strength of infrared-brazed $\mathrm{Cu} / 95 \mathrm{Ag}-5 \mathrm{Al} / \mathrm{Ti}$ specimens. The shear strengths of infrared-brazed $\mathrm{Cu} / 95 \mathrm{Ag}-5 \mathrm{Al} / \mathrm{Ti}$ specimens are between approximately 141 and $200 \mathrm{MPa}$. In addition, an SEM failure analysis was performed in order to reveal the fracture mechanism of the infrared-brazed specimen in the shear test, with the following results.

Cross sections of the aforefractured specimens were mounted in epoxy and examined by SEM ${ }^{[7]}$ Figure 11 shows the cross section of the Ti/95Ag-5Al/Cu joint after shear test infrared brazing for various brazing conditions. The BSE images are chosen for the SEM failure analysis. Distortion of the infraredbrazed joint is observed due to high flow stress in the shear test, as shown in Figure 11(c) by an arrow. All infrared-brazed specimens were fractured along the interfacial reaction layer between $\mathrm{Ti}$ and the braze alloy. Additionally, the aforementioned EPMA chemical analyses demonstrate that the $\mathrm{AlCu}_{2} \mathrm{Ti}$ phase dominates the interfacial reaction between the braze and Ti substrate. The hardness of the $\mathrm{AlCu}_{2} \mathrm{Ti}$ phase is as high as $\mathrm{Hv} 700{ }^{[15]} \mathrm{It}$ is reasonable to infer that the interfacial $\mathrm{AlCu}_{2} \mathrm{Ti}$ is brittle and detrimental to its bonding strength. Figure 12 shows fractographs after shear test for specimens infrared brazed at various brazing conditions. The fractured surface is primarily composed of cleavage instead of ductile dimple fracture. It is thus reasonable to conclude that the interfacial $\mathrm{AlCu}_{2} \mathrm{Ti}$ reaction layer is brittle, and its formation undermines the shear strength of the infrared-brazed joint.

The X-ray structural analyses of the fractured surfaces after shear test for specimens infrared brazed at various conditions are also performed. The experimental results demonstrate that the characteristic reflections of silver, copper, and $\mathrm{Ti}$ are widely observed in the X-ray data, which is agreement with the previous EPMA chemical analysis results. In addition, the X-ray reflections of interfacial $\mathrm{Ti}_{2} \mathrm{Cu}$ are weak because of its low thickness. Unfortunately, the X-ray analysis of the $\mathrm{AlCu}_{2} \mathrm{Ti}$ phase cannot be accurately identified due to insufficient structural data available in the JCPDS data bank. 

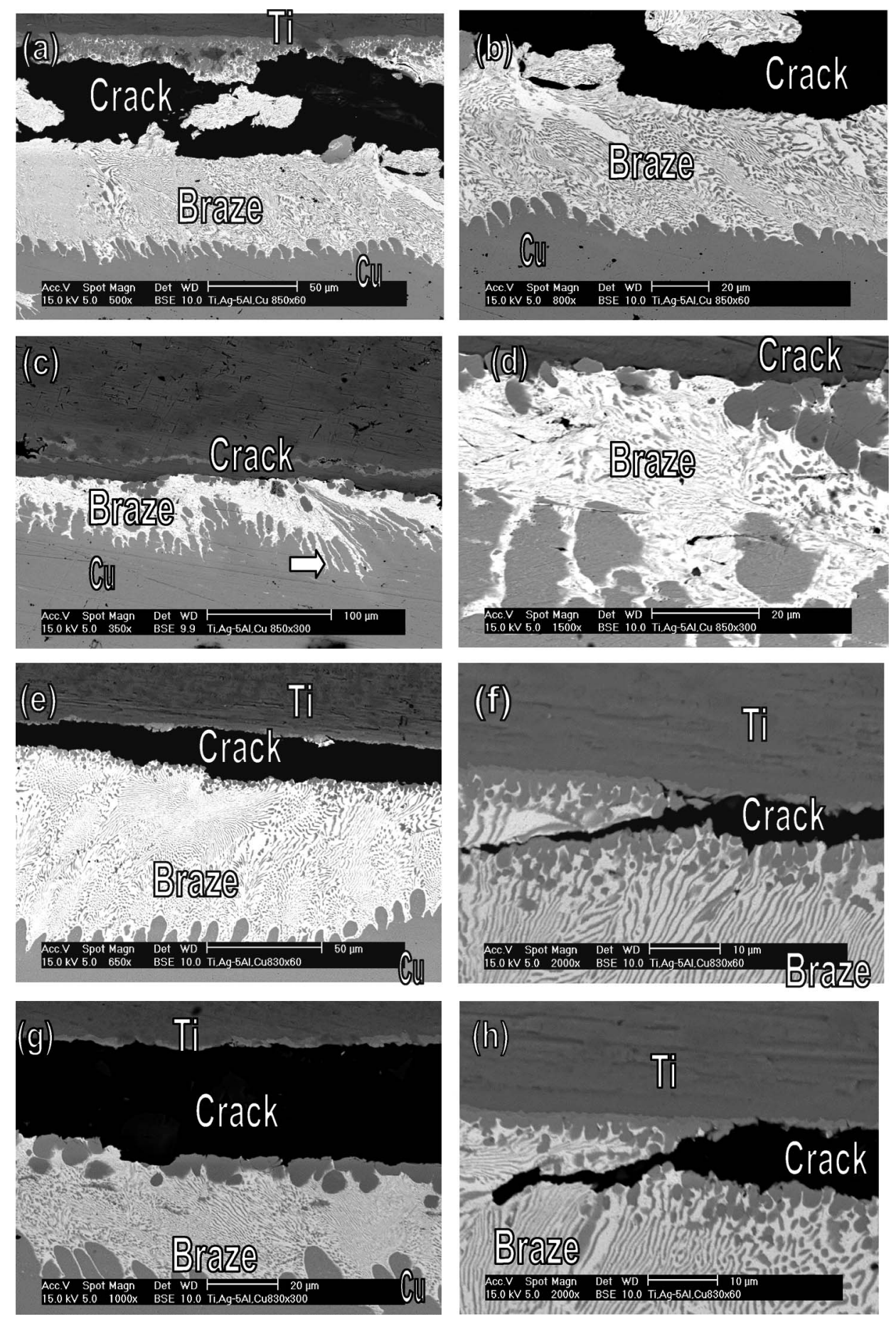

Fig. $11-$ Cross section of the Ti/95Ag-5Al/Cu joint after shear test infrared brazed at $(a)$ and $(b) 850{ }^{\circ} \mathrm{C}, 60 \mathrm{~s} ;(c)$ and $(d) 850{ }^{\circ} \mathrm{C}, 300 \mathrm{~s} ;(e)$ and $(f) 830{ }^{\circ} \mathrm{C}$, $60 \mathrm{~s}$; and $(g)$ and $(h) 830^{\circ} \mathrm{C}, 300 \mathrm{~s}$.

\section{CONCLUSIONS}

The microstructural evolution and bonding strength of the infrared-brazed $\mathrm{Cu} / 95 \mathrm{Ag}-5 \mathrm{Al} / \mathrm{Ti}$ joint were experimentally assessed. The primary conclusions are summarized as follows.

1. The wetting angle of the molten braze on the Ti substrate tested at $830{ }^{\circ} \mathrm{C}$ is as high as $100 \mathrm{deg}$, and the wetting angle rapidly decreases with increasing brazing temperature. The molten $95 \mathrm{Ag}-5 \mathrm{Al}$ braze can completely wet the Ti substrate at $900{ }^{\circ} \mathrm{C}$ after 65 seconds. In contrast, the molten braze demonstrates excellent wettability on $\mathrm{Cu}$ substrate for all testing temperatures.

2. For specimens infrared brazed at $900{ }^{\circ} \mathrm{C}$, the molten braze tends to separate into two liquids, an Ag-rich liquid and a liquid rich in $\mathrm{Cu}$ and Ti. The Ag-rich liquid flows out of the joint, so only the liquid rich in $\mathrm{Ti}$ and $\mathrm{Cu}$ is left in the joint after brazing. The infrared-brazed joint consists mainly of $\mathrm{Cu}_{2} \mathrm{Ti}$ and $\mathrm{Cu}_{4} \mathrm{Ti}$. Additionally, both $\mathrm{CuTi}$ and $\mathrm{Cu}_{4} \mathrm{Ti}_{3}$ are observed at the interface between the braze and $\mathrm{Ti}$ substrate. 

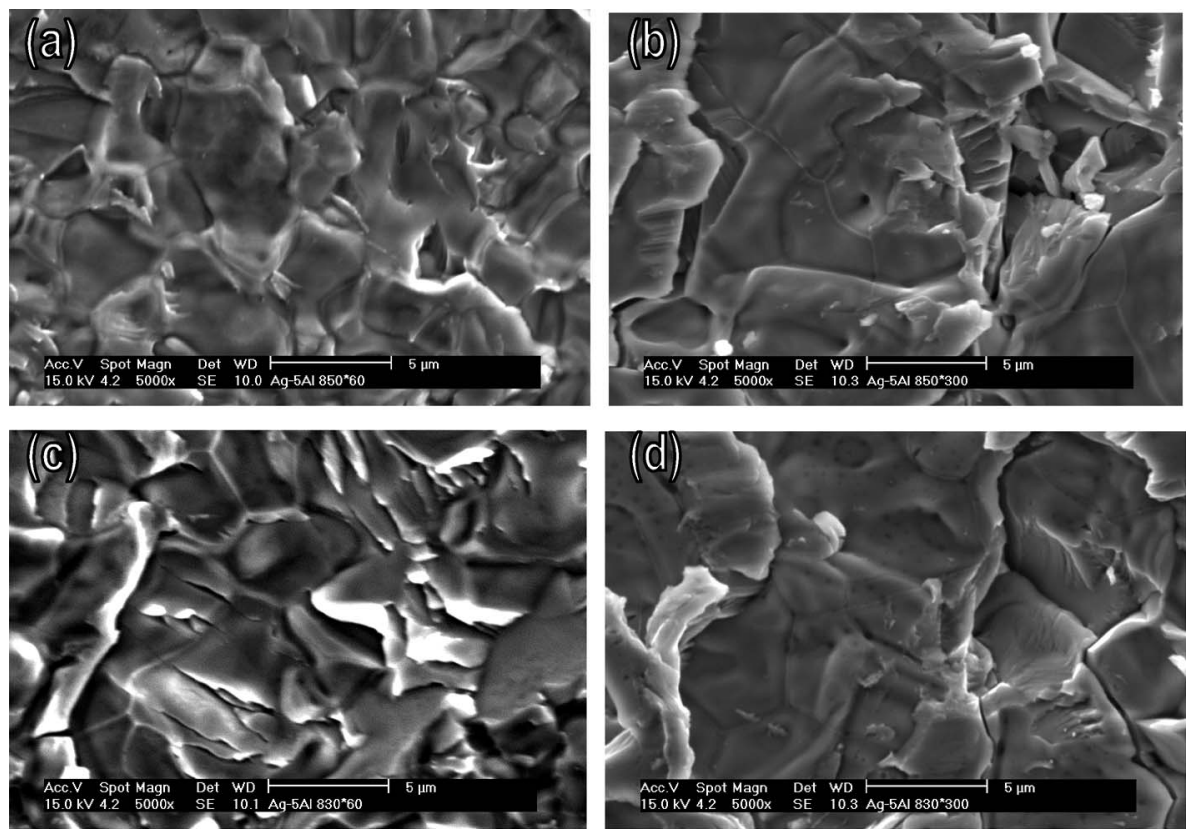

Fig. 12-Fractographs after shear test for specimens infrared brazed at $(a) 850{ }^{\circ} \mathrm{C}, 60 \mathrm{~s} ;(b) 850{ }^{\circ} \mathrm{C}, 300 \mathrm{~s} ;(c) 830{ }^{\circ} \mathrm{C}, 60 \mathrm{~s}$; and $(d) 830{ }^{\circ} \mathrm{C}, 300 \mathrm{~s}$.

3. The microstructures of specimens infrared brazed at $830{ }^{\circ} \mathrm{C}$ and $850^{\circ} \mathrm{C}$ are very different from that of the specimen infrared brazed at $900{ }^{\circ} \mathrm{C}$. The dissolution of Ti substrate significantly decreases as the brazing temperature is decreased from $900{ }^{\circ} \mathrm{C}$ into $850{ }^{\circ} \mathrm{C}$ (or $830^{\circ} \mathrm{C}$ ). Specimens infrared brazed at $830{ }^{\circ} \mathrm{C}$ and $850{ }^{\circ} \mathrm{C}$ are primarily comprised of $\mathrm{Cu}$-rich phase and $\mathrm{Ag}-\mathrm{Cu}$ eutectic. In addition, both $\mathrm{Ti}_{2} \mathrm{Cu}$ and $\mathrm{AlCu}_{2} \mathrm{Ti}$ phases are observed at the interface between the braze and Ti substrate.

4. Although the use of infrared brazing cannot completely prohibit the formation of interfacial reaction layer(s), infrared brazing provides an effective way to inhibit the growth of reaction layer(s) at the interface between the braze alloy and substrate.

5. It is advisable that the infrared brazing temperature be kept below $900{ }^{\circ} \mathrm{C}$ in order to avoid the formation of brittle phase(s) in the joint. The shear strengths of infraredbrazed specimens at $830^{\circ} \mathrm{C}$ and $850^{\circ} \mathrm{C}$ are between 160 and 198.5 MPa. All infrared-brazed specimens fracture along the interfacial $\mathrm{AlCu}_{2} \mathrm{Ti}$ reaction layer between $\mathrm{Ti}$ and the braze alloy, and extensive cleavage fracture dominates the fractured surface. Thus, the interfacial $\mathrm{AlCu}_{2} \mathrm{Ti}$ reaction layer is detrimental to the shear strength of the infrared-brazed joint.

\section{ACKNOWLEDGMENTS}

The authors gratefully acknowledge the financial support from the National Science Council (Contract No. NSC
91-2216-E002-038, Taiwan, Republic of China). The assistance of Messrs. C.Y. Wang and Y.H. Huang with the laboratory work is also gratefully acknowledged.

\section{REFERENCES}

1. G. Humpston and D.M. Jacobson: Principles of Soldering and Brazing, ASM INTERNATIONAL, Metals Park, OH, 1993, pp. 71-80.

2. D.L. Olson, T.A. Siewert, S. Liu, and G.R. Edwards: ASM Handbook, vol. 6, Welding, Brazing and Soldering, ASM INTERNATIONAL, Metals Park, OH, 1993.

3. M. Schwartz: Brazing: for the Engineering Technologist, Chapman \& Hall, New York, NY, 1995, pp. 8-10.

4. N.A. Tiner: Welding J., 1955, vol. 34, pp. 846-50.

5. C.C. Liu, C.L. Ou, and R.K. Shiue: J. Mater. Sci., 2002, vol. 37, pp. 2225-35.

6. H.Y. Chan and R.K. Shiue: J. Mater. Sci. Lett., 2003, vol. 23, pp. 1659-63.

7. R.K. Shiue, S.K. Wu, and S.Y. Chen: Acta Mater., 2003, vol. 51, pp. 1991-2004.

8. T.Y. Yang, S.K. Wu, and R.K. Shiue: Intermetallics, 2001, vol. 9 , pp. 341-47.

9. R.K. Shiue, S.K. Wu, and C.M. Hung: Metall. Mater. Trans. A, 2002, vol. 33A, pp. 1765-73.

10. R.K. Shiue, S.K. Wu, and J.M. O, and J.Y. Wang: Metall. Mater. Trans. A, 2000, vol. 31A, pp. 2527-36.

11. R.K. Shiue, S.K. Wu, and C.H. Chan: J. Alloys Compounds, 2004, vol. 372, pp. 148-57.

12. P. Villars, A. Prince, and H. Okamoto: Handbook of Ternary Alloy Phase Diagrams, ASM INTERNATIONAL Metals Park, OH, 1995.

13. G. Petzow and G. Effenberg: Ternary Alloys, VCH Publishers, New York, NY, 1988.

14. T.B. Massalski: Binary Alloy Phase Diagrams, ASM INTERNATIONAL, Metals Park, OH, 1990.

15. T. Tetsui: Intermetallics, 2001, vol. 9, pp. 253-60. 